\title{
The Nigerian Health Workers' Attitude and Knowledge of the Middle East Respiratory Syndrome
}

\author{
Article by Maclawrence Kolapo Famuyiwa, \\ PhD Public Health Student, Texila American University, Nigeria \\ Email:maclaw196@gmail.com.
}

\begin{abstract}
Background: This is a study done to assess the knowledge and attitude of health care workers in Nigeria about the Middle East Respiratory Syndrome (MERS). This study became necessary because there is now exportation of the disease from Saudi Arabia, to other countries.

Methods: It is a cross-sectional study, involving 224 respondents. Descriptive statistics was used to get the characteristics, mean attitude and knowledge scores of the study participants. Chi-square test was used to determine the relationship that exists between study variables and questions on attitude. Inferential statistics, Mann-Whitney $U$ and Kruskal Wallis tests, were used to examine differences between study variables. $P$ values $<0.05$ were considered significant. Spearman's rho correlation was employed in the identification of the association between knowledge and attitude scores.

Results: The respondents showed a fairly good knowledge and good attitude towards MERS. There was a significant correlation between knowledge and attitude ( $r=0.301, P<$ 0.001). Respondents showed poorest knowledge in thinking that MERS is still restricted to the Arabian Peninsula (8.5\%), however, they showed good knowledge in the type of people the disease is most devastated in (87.9\%). Many of the respondents demonstrated a positive attitude in the sharing of MERS related information among peers $(1.39 \pm 0.866)$ but their attitude towards their active participation in infection control is the poorest (2.49 \pm 1.242$)$.

Conclusions: This study revealed that health care workers in Nigeria have fairly good knowledge and good attitude towards MERS, but demonstrated very poor knowledge and negative attitude in some areas.
\end{abstract}

Keywords: Dromedary, MERS-CoV, Middle East, Ebola, Knowledge, Attitude

\section{Introduction}

Middle East Respiratory Syndrome (MERS), according to The Centers for Disease Control and Prevention [CDC] (2015), is a viral respiratory diseases attributable to a novel coronavirus (MERS-CoV).It was initially believed that all known cases of the disease have been limited to countries in and near the Arabian Peninsula, but cases have also been reported in Korea and China, (World Health Organisation [WHO], 2015, July 10).

This study therefore, intends to study the knowledge and attitude of Nigerian health care workers, which becomes necessary so as to establish their preparedness for prompt case identification if perchance the disease rears its ugly head like Ebola recently did in Nigeria.

\section{Materials and methods}

The study was cross sectional. It was carried out among healthcare workers in three General Hospitals in Southwest Nigeria. All categories of core health workers: doctors; nurses; pharmacist; dentist; physiotherapists; and laboratory scientists were involved.

Raosoft software (Raosoft, 2004)was employed in calculating the sample size, by setting the calculator at population size of 500, margin of error of 5\%, level of confidence of $95 \%$, and response distribution of $50 \%$, a minimum sample size of 218 was generated, so 260 questionnaires were distributed of which 224 were returned completely filled, representing a response rate of approximately $86.2 \%$. 
South American Journal of Public Health

Special Edition May 2016

Self-administered questionnaires were used as the instrument for data collection, which was constructed after the results of a pilot study, was used to edit and correct anomalies in the standard questionnaire. The contents of the questionnaire that was finally used, have reliability coefficient calculated using SPSS v.20 and the value of Cronbach's alpha (Cronbach, 1951) was 0.715 , and was divided into 4 parts. The first part was about information about the general characteristics of the respondents. The second part was about the source of respondents' MERS knowledge. The third part examined the healthcare workers' knowledge of MERS using a Yes or No option against each set of question. The final part was about the attitude of respondents towards MERS and their response were evaluated through 5 point Likert scale of agreement.

The questionnaire was used to assess the knowledge of the healthcare workers studied by asking questions about the nature, aetiology, symptoms, risk group, consequences, source of transmission, prevention and treatment of MERS-CoV. Knowledge scores ranged from 0-14 and scores of $<10$ were taken for poor knowledge and $\geq 10$ for good knowledge. Attitude was assessed using a 7 item questions and the responses were recorded on 5 point Likert scale. A score of 1 was assigned to strongly agree, 2 to agree, 3 to undecided, 4 to disagree and 5 to strongly disagree. Amean score of $\leq 2$ was considered as positive attitude while that of 3-5 was taken as negative attitude.

\section{Data analysis}

Data analysis was for bio-data, response regarding their knowledge of the disease as well as their attitude towards the disease and the management of confirmed cases. IBM SPSS 20 was used in the analysis of the data; descriptive statistics was used to get the general characteristics of the study participants. Chi-square test was used to determine the level of significance of groups of categorical variables. P values $<0.05$ were considered significant. The inferential statistics was done using Mann-Whitney U test and Kruskal Wallis tests, $\mathrm{p}<$ -0.05 , for the assessment of the significance among study variables, these non-parametric tests were preferred over Kolmogorov-Smirnov and Shapiro-Wilks tests because of the nonnormal distribution of the data as shown by the significant $\mathrm{P}$ value $(\mathrm{P}<0.05)$ for both Kolmogorov-Smirnov and Shapiro-Wilks tests value, and the choice of non-parametric tests was also because of the smallness of the sample size, this also explained why Spearman's rank correlation coefficient $(p<0.05)$ was used for the evaluation of the association between knowledge and attitude.

\section{Ethical approval}

Ethical approval was obtained before the commencement of the study from the Research Committees of the three hospitals, and written permission was obtained from the participants before the administration of the questionnaires. 


\section{Results}

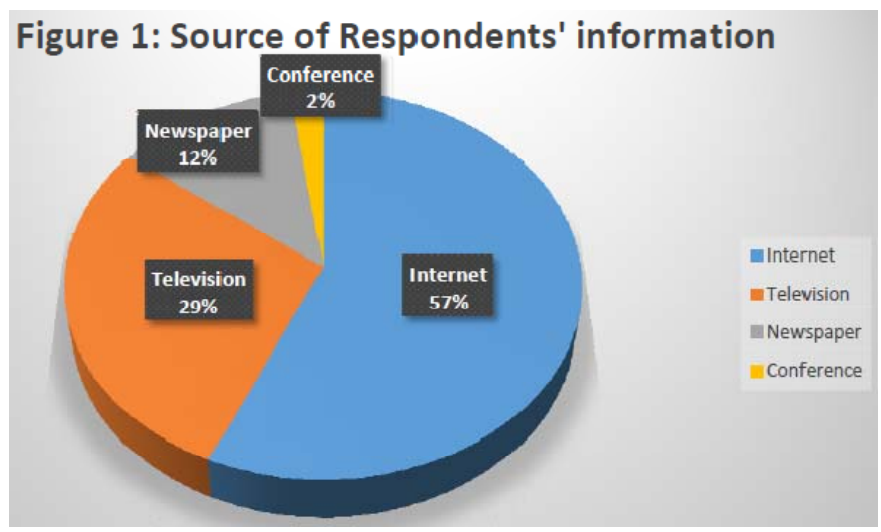

Figure 1 shows that 127 out of the 224 respondents representing about $57 \%$ of the respondents got their information from the internet, 29\% (64 respondents) got their information from the television while 26 respondents representing $12 \%$ of the respondents got their information from the newspapers.

Table 1: Age Distributions

\begin{tabular}{|l|l|l|}
\hline Age Range & Number of Respondents & Percentage \\
\hline $21-30$ & 77 & 34.4 \\
\hline $31-40$ & 65 & 29.0 \\
\hline $41-50$ & 48 & 21.4 \\
\hline $51-60$ & 34 & 15.2 \\
\hline & $\mathbf{2 2 4}$ & $\mathbf{1 0 0 . 0}$ \\
\hline
\end{tabular}

Table 1 shows that $34.4 \%$ of the respondents are within the $21-30$ age range, $29.0 \%$ within the age range $31-40$ and $21.4 \%$ within the age range $41-50$. The median age is 35.9 years, the mode is 29.2 years, and the mean is 37.2 years.

Table 2: Distribution of respondents by gender and profession

\begin{tabular}{|l|l|l|l|l|l|l|l|}
\hline Gender & $\begin{array}{l}\text { Medical } \\
\text { Doctors }\end{array}$ & Dentists & Pharmacists & $\begin{array}{l}\text { Physio- } \\
\text { therapists }\end{array}$ & $\begin{array}{l}\text { Laboratory } \\
\text { Scientists }\end{array}$ & Nurses & $\begin{array}{l}\text { Total } \\
\mathbf{( \% )}\end{array}$ \\
\hline Male & 28 & 20 & 15 & 12 & 15 & 7 & $\begin{array}{l}\mathbf{9 7} \\
\mathbf{( 4 3 . 3 )}\end{array}$ \\
\hline Female & 22 & 16 & 13 & 12 & 17 & 47 & $\begin{array}{l}\mathbf{1 2 7} \\
\mathbf{( 5 6 . 7 )}\end{array}$ \\
\hline $\begin{array}{l}\text { Total } \\
(\%)\end{array}$ & $\begin{array}{l}\mathbf{5 0} \\
\mathbf{( 2 2 . 3 )}\end{array}$ & $\begin{array}{l}\mathbf{3 6} \\
\mathbf{( 1 6 . 1 )}\end{array}$ & $\begin{array}{l}\mathbf{2 8} \\
\mathbf{( 1 2 . 1 )}\end{array}$ & $\begin{array}{l}\mathbf{2 4} \\
\mathbf{( 1 0 . 7 )}\end{array}$ & $\begin{array}{l}\mathbf{3 2} \\
\mathbf{( 1 4 . 3 )}\end{array}$ & $\begin{array}{l}\mathbf{5 4} \\
\mathbf{( 2 4 . 1 )}\end{array}$ & $\begin{array}{l}\mathbf{2 2 4} \\
\mathbf{( 1 0 0 )}\end{array}$ \\
\hline
\end{tabular}

The female accounted for $56.7 \%$ of the respondents while the male constitutes the remaining $43.3 \%$. Also $24.1 \%$ of the respondents belong to the Nursing profession while $22.3 \%$ are medical doctors and $16.1 \%$ are dentists, of the rest $37.5 \%, 14.3 \%$ are laboratory scientists, $12.1 \%$ are pharmacists and $10.7 \%$ are physiotherapists. This can be seen from Table 2 above.

Table 3: Years of Professional Experience

\begin{tabular}{|l|l|c|}
\hline Years of Experience & Number of Respondents & Percentage \\
\hline $\mathbf{0 - 4}$ & 83 & 37.1 \\
\hline $\mathbf{5 - 9}$ & 73 & 32.6 \\
\hline $\mathbf{1 0 - 1 4}$ & 36 & 16.1 \\
\hline $\mathbf{1 5 - 1 9}$ & 32 & 14.3 \\
\hline Total & $\mathbf{2 2 4}$ & $\mathbf{1 0 0 . 0}$ \\
\hline
\end{tabular}


South American Journal of Public Health

Special Edition May 2016

Table 3 shows that the majority of the respondents $(69.7 \%)$ have less than 10 years professional experience, with those having between $0-4$ years accounting for $37.1 \%$ while those with 5-9 years accounting for the remaining 32.6\%. $16.1 \%$ of the remaining $30.4 \%$ of the respondents have between 10-14 years professional experience, while the other $14.3 \%$ have between 15-19 years professional experience. The mean year of professional experience is 7.4 years, while the mode year of professional experience is 4.0 years and the median year of professional experience is 4.9 years.

TABLE 4: Knowledge about MERS

\begin{tabular}{|c|c|c|}
\hline \multirow[t]{2}{*}{ Knowledge of MERS } & \multicolumn{2}{|l|}{ Responses } \\
\hline & Correct & Wrong \\
\hline MERS is caused by a rotavirus & $130(58.0)$ & $94(42.0)$ \\
\hline Incubation period for MERS Co-V is $10-21$ days & $65(29.0)$ & $159(71.0)$ \\
\hline Cat is possibly a source of human infection & $115(51.3)$ & $109(48.7)$ \\
\hline $\begin{array}{l}\text { Washing hands often with soap and water for at least } 20 \text { seconds, or } \\
\text { using an alcohol-based hand sanitizer, if soap and water are not } \\
\text { available can help prevent being infected with MERS Co-V. }\end{array}$ & $135(60.3)$ & $89(39.7)$ \\
\hline $\begin{array}{l}\text { Close contacts with diseased persons can lead to the spread of the } \\
\text { disease. }\end{array}$ & $121(54.0)$ & $103(46.0)$ \\
\hline $\begin{array}{l}\text { Real-time reverse-transcription polymerase chain reaction (rRT- } \\
\text { PCR) assays are molecular tests that can be used to detect MERS } \\
\text { Co-V RNA in clinical samples }\end{array}$ & $126(56.3)$ & $98(43.7)$ \\
\hline Antibiotics are first line treatment. & $159(71.0)$ & $65(29.0)$ \\
\hline Current treatment includes care to support vital organ functions. & $178(79.5)$ & $46(20.5)$ \\
\hline Symptoms include fever, cough and shortness of breath, pneumonia & $142(63.4)$ & $82(36.4)$ \\
\hline MERS patients develop severe acute respiratory illness & $132(58.9)$ & $92(41.1)$ \\
\hline There is a vaccine for MERS Co-V. & $167(74.6)$ & $57(25.4)$ \\
\hline MERS is only restricted to the Arabian peninsula as of now. & $19(8.5)$ & $205(91.5)$ \\
\hline $\begin{array}{l}\text { The virus appears to be more devastating in older people, people } \\
\text { with weakened immune systems, and those suffering from chronic } \\
\text { diseases }\end{array}$ & $197(87.9)$ & $27(12.1)$ \\
\hline MERS can be fatal. & $154(68.8)$ & $70(31.3)$ \\
\hline
\end{tabular}

Note: Knowledge was assessed by assigning 1 to correct answer and 2 to wrong answer. The scale measured knowledge of maximum 14 to minimum 0 . Scores of $<10$ were taken as poor while $\geq 10$ as good. Mean knowledge score was $9.95 \pm 2.639$. 
Table 4 shows the current status of MERS knowledge among healthcare workers. One hundred and thirty nine (139) representing $62.1 \%$ of the respondents exhibited a good knowledge of MERS while eighty five (85) representing $37.9 \%$ of the respondents demonstrated poor knowledge of MERS. The poorest knowledge by the respondents as shown in this study was the belief by the $91.5 \%$ of the respondents that MERS is still restricted to the Arabian peninsula, this was followed by the knowledge of the incubation period of the virus which attracted a wrong response rate of $71 \%$, this was followed by a wrong response rate of $48.8 \%$ for the possible source of human infection. Mean knowledge score of healthcare worker was $9.95 \pm 2.693$.

Table 5: Attitude of health workers towards MERS

\begin{tabular}{|c|c|c|c|c|c|c|c|c|c|}
\hline \multirow[b]{2}{*}{ Item } & \multicolumn{5}{|c|}{ Responses* } & \multicolumn{4}{|c|}{ P-Values** } \\
\hline & SA & A & $\mathbf{U}$ & D & SD & $\begin{array}{l}\text { Profes } \\
\text { sional }\end{array}$ & Gender & Age & Experience \\
\hline $\begin{array}{l}\text { Isolate those } \\
\text { identified as at risk } \\
\text { for or confirmed for } \\
\text { having MERS- } \\
\text { CoVinfection }^{\text {a }}\end{array}$ & 110 & 58 & 46 & 10 & $\mathbf{0}$ & 0.001 & 0.097 & 0.071 & 0.017 \\
\hline $\begin{array}{l}\text { Transmission of } \\
\text { MERS-CoV } \\
\text { infection can be } \\
\text { prevented by using } \\
\text { universal } \\
\text { precautions } \mathbf{b}\end{array}$ & 158 & 40 & 12 & 0 & 14 & 0.126 & 0.034 & 0.025 & 0.002 \\
\hline $\begin{array}{l}\text { Any related } \\
\text { healthcare } \\
\text { information about } \\
\text { MERS should be } \\
\text { disseminated, } \\
\text { among peers and } \\
\text { others }\end{array}$ & 175 & 25 & 12 & 9 & 3 & 0.498 & 0.004 & 0.032 & 0.039 \\
\hline $\begin{array}{l}\text { MERS patients } \\
\text { should be given } \\
\text { Intensive and } \\
\text { emergency } \\
\text { treatment }^{\text {d }}\end{array}$ & 75 & 97 & 18 & 4 & 30 & 0.029 & 0.332 & 0.289 & 0.196 \\
\hline $\begin{array}{l}\text { PPEs, gowns, } \\
\text { gloves, mask and } \\
\text { googles must be } \\
\text { worn and disposed } \\
\text { off when dealing } \\
\text { with MERS patients }\end{array}$ & 57 & 78 & 48 & 12 & 29 & 0.178 & 0.074 & 0.007 & 0.002 \\
\hline $\begin{array}{l}\text { Active participation } \\
\text { of health care } \\
\text { worker in hospital } \\
\text { infection control } \\
\text { program can help to } \\
\text { reduce MERS } \\
\text { infection }{ }^{\mathrm{f}}\end{array}$ & 64 & 48 & 70 & 23 & 19 & 0.011 & 0.081 & 0.006 & 0.025 \\
\hline $\begin{array}{l}\text { Healthcare workers } \\
\text { in Nigeria should } \\
\text { find more }\end{array}$ & 44 & 92 & 52 & 12 & 24 & 0.249 & 0.093 & 0.016 & 0.027 \\
\hline
\end{tabular}


South American Journal of Public Health

Special Edition May 2016

\begin{tabular}{|l|l|l|l|l|l|l|l|l|l|}
\hline $\begin{array}{l}\text { information about } \\
\text { MERS }^{\mathrm{g}}\end{array}$ & & & & & & & & & \\
\hline
\end{tabular}

*SA = strongly agree, $\mathrm{A}=$ Agree, $\mathrm{U}=$ Undecided, $\mathrm{D}=$ Disagree, $\mathrm{SD}=$ strongly disagree.

**Derived from Chi-square test.

Note: Attitude was assessed by giving 1 to SA, 2 to A, 3 to U, 4 to D, 5 to SD. Score of $\leq 2$ were taken as positive attitude while 2 as negative attitude. Mean attitude score was $1.29 \pm$ 0.453 .

Mean attitude score \pm SD: $:{ }^{\mathrm{a}} 1.80 \pm 0.917,{ }^{\mathrm{b}} 1.47 \pm 0.857,{ }^{\mathrm{c}} 1.39 \pm 0.866,{ }^{\mathrm{d}} 2.18 \pm 1.291,{ }^{\mathrm{e}} 2.46$ $\pm 1.284,{ }^{\mathrm{f}} 2.49 \pm 1.242,{ }^{\mathrm{g}} 2.46 \pm 1.182$.

Table 5 shows that the most negative attitude shown by the respondents was in response to the question asked about the active participation of health care worker in hospital infection control can help to reduce MERs infection. One hundred and sixty (160) representing 71.4\% of the 224 respondents demonstrated a positive attitude about MERS while $64(28.6 \%)$ of the respondents showed negative attitude about MERS.

Table 6: Mean score of knowledge and attitude

\begin{tabular}{|l|l|l|l|l|l|l|l|}
\hline Description & $\mathbf{N}$ & $\begin{array}{l}\text { Knowledge } \\
\text { score (Mean } \pm \\
\text { SD) }\end{array}$ & $\begin{array}{l}\text { Mean } \\
\text { rank }\end{array}$ & $\begin{array}{l}\text { P } \\
\text { value }\end{array}$ & $\begin{array}{l}\text { Attitude } \\
\text { score (Mean } \\
\pm \text { SD) }\end{array}$ & $\begin{array}{l}\text { Mean } \\
\text { rank }\end{array}$ & $\begin{array}{l}\text { P } \\
\text { value }\end{array}$ \\
\hline Age* & 77 & $9.81 \pm 2.753$ & 108.94 & 0.326 & $1.32 \pm 0.471$ & 116.86 & 0.018 \\
\hline $21-30$ & & & & & & \\
\hline $31-40$ & 65 & $10.40 \pm 2.536$ & 122.86 & & $1.14 \pm 0.348$ & 96.01 & \\
\hline $41-50$ & 48 & $9.87 \pm 2.803$ & 113.79 & & $1.35 \pm 0.483$ & 120.17 & \\
\hline $51-60$ & 34 & $9.53 \pm 2.299$ & 98.94 & & $1.38 \pm 0.493$ & 123.32 & \\
\hline Gender** & & & & & & & \\
\hline Male & 97 & $9.91 \pm 2.610$ & 110.86 & 0.738 & $1.21 \pm 0.407$ & 103.59 & 0.022 \\
\hline Female & 127 & $9.98 \pm 2.670$ & 113.76 & & $1.35 \pm 0.478$ & 119.30 & \\
\hline Profession* & & & & & & & \\
\hline Physicians & 50 & $10.06 \pm 2.630$ & 115.53 & 0.865 & $1.28 \pm 0.454$ & 111.86 & 0.010 \\
\hline Dentists & 36 & $10.03 \pm 2.501$ & 111.15 & & $1.39 \pm 0.494$ & 124.06 & \\
\hline Pharmacists & 28 & $9.39 \pm 2.644$ & 97.52 & & $1.50 \pm 0.509$ & 136.50 & \\
\hline $\begin{array}{l}\text { Physiotherapis } \\
\text { ts }\end{array}$ & 24 & $9.83 \pm 3.102$ & 115.10 & & $1.33 \pm 0.482$ & 117.83 & \\
\hline Lab Scientists & 32 & $10.13 \pm 2.225$ & 114.30 & & $1.13 \pm 0.336$ & 94.50 & \\
\hline Nurses & 54 & $10.04 \pm 2.815$ & 116.14 & & $1.19 \pm 0.392$ & 101.24 & \\
\hline Experience* & & & & & & & \\
\hline $0-4$ & 83 & $9.75 \pm 2.654$ & 107.48 & 0.570 & $1.13 \pm 0.341$ & 95.34 & 0.000 \\
\hline $5-9$ & 73 & $10.14 \pm 2.694$ & 116.65 & & $1.26 \pm 0.442$ & 109.65 & \\
\hline $10-14$ & 36 & $10.00 \pm 2.726$ & 115.39 & & $1.50 \pm 0.507$ & 136.50 & \\
\hline$>14$ & 32 & $10.00 \pm 2.449$ & 112.81 & & $1.50 \pm 0.508$ & 136.50 & \\
\hline & & & & & & \\
\hline
\end{tabular}

*Kruskal Wallis Test $(\mathrm{p}<0.05)$.

**Mann Whitney Test $(\mathrm{p}<0.05)$.

Table 6 shows that the respondents in the 31-40 years age group showed most knowledge compared to those in the 51-60 year age group with the least knowledge (10.4 vs $9.53, \mathrm{p}=$ $0.326)$ and with the most positive attitude $(1.14$ vs $1.38, \mathrm{p}=0.018)$ towards MERS as compared to those in the 51-60 years age group. Similarly, the laboratory science professional showed most knowledge compared with the pharmacy professionals showing the least knowledge $(10.13$ vs $9.39, \mathrm{p}=0.865)$ but with the least attitude $(1.13$ vs $1.50, \mathrm{p}=0.010)$ 
towards MERS when compared to the pharmacy professionals who showed the most knowledge.

The spearman correlation test revealed significant positive relationship between knowledge and attitude of healthcare workers about MERS $(r=0.301, p<0.05)$.

\section{Discussion}

Majority of the respondents $(63.4 \%)$ are between 21 years and 40 years in age, and there is preponderance of the respondents $(69.7 \%)$ between 1 and 9 years experience. The high proportion $(87 \%)$ of female gender amongst those in the nursing profession might have tilted the majority of the respondents $(56.7 \%)$ being female.

The respondents showed fairly good knowledge of MERS Co-V but with good positive attitude. Majority of the respondents (57\%) gained their knowledge about MERS from the internet, a new trend for health care workers to get information about health (Rapparini, et al, 2007), this more than double the proportion that got their information from the internet in a similar study (Khan et al, 2014).

Like it is with most health authorities all over the world, there is a dearth of information on MERS in Nigeria, more pre-occupation is on Ebolathan on any other global infectious disease threats (Zumla et al, 2014). This also extend to the availability of previous reports of similar studies on healthcare workers' knowledge and attitude towards MERS, which makes comparison of the findings in this study with other related conditions like Ebola Virus Disease (EVD) and Severe Acute Respiratory Syndrome (SARS) inevitable.

Ninety one percent $(91.5 \%)$ of the healthcare workers were least knowledgeable in the question regarding the restriction of MERS to the Arabian Peninsula, this may be influenced by the prevailing scientific belief before May 2015 (Embarek and Kerkhove, 2015), that MERS was restricted to the Arabian Peninsula, which has been debunked by the reporting of the first case of a MERS-coronavirus (MERS-CoV) infection in South Korea on 20 May 2015 (WHO, 2015, May $30^{\text {th }}$ ). Majority of correct answers to this question was given by respondents having 10 years professional experience and those that are $\leq 40$ years in age, this may be because they are the most active on the internet, the source from which the majority of the respondents got their information about MERS from.

Also $71 \%$ of the respondents gave a wrong response to the incubation period of the MERS $\mathrm{Co}-\mathrm{V}$, this was contrary to the $19.6 \%$ given by the those in a similar study (Khan et al, 2014), the difference may be because of lack of practical experience the majority of the respondent in this study has about MERS compared to that in the comparative study where the disease is currently of public health concern, Most of the correct response for this question, was by $\geq 10$ years experience.

About $49 \%$ and $46 \%$ of the respondents gave incorrect answers to the questions about the animal and human to human transmission of the disease respectively, this time around, those 10 years professional experience gave the most correct response. Matter of fact, camel has been associated as the possible source of MERS (Pittet, et al., 2000) and humans could be a source of transmission of this disease as well (Hawkes, 2013).

The study also revealed the mean attitude score to be in the positive range $(1.29 \pm 0.453)$ with the most positive attitude shown by the health workers in this study, being about free dissemination of information about MERS amongst peers $(1.39 \pm 0.866)$, this finding is similar to the study by Khan et al, in 2014. It was observed also that gender, age and experience were significantly associated with this question with the male gender proportionately positively responded to this question more than the female gender, so also were those 40 years showing more positive attitudes compared to those 40 years in this study, and also those with $\leq 10$ years professional work experience showed better positive attitude than those 40 years of age and 10 years experience.

However, the most negative attitude was shown by the respondents towards the question about active participation of health workers in infection control programmes to reduce the prevalence of MERS. This was significantly related to age, profession and experience of the 
respondents, with those 40 years negatively responded to this question more than those 40 years, and those of the pharmacy profession with the least positive response and those of the laboratory science profession with the most positive response while those with $\geq 10$ years experience gave least positive response to this question compared to those with 10 years profession work experience. This result was also in accordance with Khan, et al. study while it was in contrary to another study where it was actually observed that the highest positive attitude of health workers was towards active participation in hospital control program (Rahnavardi et al., 2008). The hierarchical nature of health profession where junior health workers are made to have more active participation in patients' management probably reflected in the most positive response from 40 years of age and with 10 years professional experience to this question. Also, the laboratory science professionals showing most positive response to this question may be more out of the fact that they handle many infectious samples from patients, so they have consciously or unconsciously ingrained infection control attitude more than other health care workers, and the least positive response shown by those in the pharmacy profession is also probably due to the fact that they are least exposed directly to patients or infectious materials from these patients, so their infection control attitude is least developed. This study however, showed a sharp disagreement with other similar studies that observed that physicians are the ones that showed most positive attitude (Joukar, et al., 2012, Khan et al., 2014, \&Richmond, et al 2007).

The strength of this study is the delving into an area where very little research has been done, this is helped by the high response rate, so the findings of this study will come handy in preparing and designing effective control measures of MERS in Nigeria. The validation of the questionnaire adopting a development approach, with some modifications using a pilot study is also a strength of this study.

The limitation of this study is the statistical errors that multiple significance testing may introduce to the generalizability of the results so also is the potential sample clustering.

\section{Recommendations}

1. Since most of the respondents in this study relies more on the internet as a source of information about MERS as a result of dearth of information from the health authorities in Nigeria. It is expedient that more conferences, seminars and fora should be organized to improve the knowledge and attitude of Nigerian health care workers, so that they will be able to decipher useful information from useless ones over the internet.

2. Serious attention should be paid into increasing health awareness about MERS, even though current data does not support the readily transmissibility of MERS-CoV, as was observed with the SARS-CoV epidemic in 2003, however, continued risk assessment, surveillance, and vigilance are required(Peiris JS, Chu CM, Cheng VC, et al., 2003).

3. It will then be medically expedient to train health workers to have a high degree of clinical suspicion for the possibility of MERS-CoV infection in patients with respiratory infections who have visited the Middle East in the preceding 10 days, going by the fact that Nigerian Muslims are among millions of pilgrims that annually visit Mecca, Saudi Arabia, the epicenter of the current MERS epidemic and from where the disease has majorly been exported to other countries that the disease has been reported

4. The preponderance of overall seropositive adult dromedary camels in Nigeria (Chantal, et al., 2014), animals in which current available information has been associated as probably being the source of human infections, means more efforts should be geared towards educating the handlers of these animals about all preventive practices so as to prevent possible animal to man transmission of the MERS Co-V.

\section{Conclusion}

This study showed that health care workers in Nigeria showed good positive attitude and fairly good knowledge of MERS. It also revealed that more efforts should be geared towards 
an improvement in some aspects of their knowledge such as the possible sources of virus transmission, the reality of MERS already extending beyond the Arabian Peninsula, the incubation period and the diagnosis of MERS. There is therefore, a need for more and an allinclusive health education campaigns to augment the current knowledge of health care workers to be at par with the required knowledge with more emphasis on areas where their knowledge is low. It will also be beneficial for health care workers if their attitude towards MERS can be given a lift through a well thought out professional and occupational measures. Also since very few researches have been done on this disease, more researches should be encouraged to study in more details, especially the connection between high sero-possitivity found in dromedary camels in Nigeria and the possibility of silent ravaging of MERS in Nigeria or otherwise.

Declaration: The author declare no conflicts of interest.

\section{References}

[1.] Chantal B. E. M. Reusken; Lilia Messadi; Ashenafi Feyisa; Hussaini Ularamu; Gert-Jan Godeke; Agom Danmarwa; Fufa Dawo; Mohamed Jemli; Simenew Melaku; David Shamaki; Yusuf Woma; Yiltawe Wungak; Endrias Zewdu Gebremedhin; Ilse Zutt, Berend-Jan Bosch; Bart L. Haagmans; Marion P. G. Koopmans. Geographic Distribution of MERS Coronavirus Among Dromedary Camels, Africa. Emerging Infectious Diseases. 2014;20(8):1370-1374.

[2.] CDC (2015, July $\left.6^{\text {th }}\right)$. Middle East respiratory syndrome (MERS). Centre for Disease Control and Prevention (2015). Available at: http://www.cdc.gov/coronavirus/mers/about/index.html

[3.] Cronbach L J (1951) Coefficient alpha and the internal structure of tests. Psychometrika 16:297334.

[4.] Embarek P K, Kerkhove V. Middle East respiratory syndrome coronavirus (MERS-CoV) -current situation 3 years after the virus was first identified. Wkly Epidemiol Rec 2015 May 15;90:245-50.

[5.] Joukar F, Mansour-Ghanaei F, Soati F, Meskinkhoda P: Knowledge level and attitudes of health care professionals toward patients with hepatitis C infection. World J Gastroenterol 2012, 8:22382244.

[6.] Hawkes N: Camels could be the source of MERS coronavirus, research finds. BMJ 2013, 347:f5052.

[7.] Khan, M. U, Shah, S. and Fatokun, O. (2014): Knowledge and attitude of healthcare workers about middle east respiratory syndrome in multispecialty hospitals of Qassim, Saudi Arabia. BMC Public Health 2014 14:1281. doi:10.1186/1471-2458-14-1281.

[8.] Peiris JS, Chu CM, Cheng VC, et al. Clinical progression and viral load in a community outbreak of coronavirus-associated SARS pneumonia: a prospective study. Lancet2003;361:1767-1772 CrossRef | Web of Science | Medline

[9.] Pittet D, Hugonnet S, Harbarth S, Mourouga P, Sauvan V, Touveneau S, Perneger TV, members of the infection control programme: Effectiveness of a hospital-wide programme to improve compliance with hand hygiene. Lancet 2000, 356:1307-1312.

[10.] Raosoft (2004). Sample size calculator. Accessed on $17^{\text {th }}$ July, 2015 at:

http://www.raosoft.com/samplesize.html

[11.] Rapparini C, Feijó-Barroso P, Saraceni V, Artioli-Machado A, CôrtesFernandes G (2007):

Occupationally acquired infectious diseases among health care workers in Brazil: use of internet tools to improve management, prevention, and surveillance. Am J Infect Control 2007, 35:267-270.

[12.] Rahnavardi M, Rajaeinejad M, Pourmalek F, Mardani M, Holakouie-Naieni K,Dowlatshahi S (2008): Knowledge and attitude toward Crimeane Congo haemorrhagic fever in occupationally at-risk Iranian healthcare workers. J Hosp Infect 2008, 69:77-85.

[13.] Richmond JA, Dunning TL, Desmond PV (2007): Health professionals' attitudes toward caring for people with hepatitis C. J Viral Hepat 2007, 14:624-632.

[14.] WHO. Middle East respiratory syndrome coronavirus (MERS-CoV) - Republic of Korea.

Disease outbreak news (2015, May 30). Geneva: World Health Organization, 2015.

http://www.who.int/csr/don/01-june-2015-merskorea/en/ (accessed July 16, 2015). 
South American Journal of Public Health

Special Edition May 2016

[15.] Zumla A, Perlman S, McNabb S J, Shaikh A, Heymann D L, McCloskey B, et al (2015). Middle East respiratory syndrome in the shadow of Ebola. Lancet Respir Med 2015 Feb;3(2):100-2. 